\title{
Antisickling properties, thermal and photochemical degradations of anthocyanin extracts from Annona senegalensis (Annonaceae)
}

\author{
P.T. MPIANA ${ }^{1 *}$, E.N. DIANZENZA ${ }^{1}$, K.N. NGBOLUA ${ }^{2}$, D.S.T. TSHIBANGU ${ }^{1}$, B.M. \\ MBALA $^{1}$, S.O. MIHIGO ${ }^{1}$, E.K. ATIBU ${ }^{1}$, M.K. KAKULE ${ }^{3}$ and M.T. BOKOTA ${ }^{4}$ \\ ${ }^{I}$ Département de Chimie, Faculté des Sciences, B.P. 190, Université de Kinshasa, Kinshasa XI, D.R. Congo. \\ ${ }^{2}$ Département de Biologie, Faculté des Sciences, B.P. 190, Université de Kinshasa, Kinshasa XI, D.R.Congo. \\ ${ }^{3}$ Département de Physique, Faculté des Sciences, B.P. 190, Université de Kinshasa, Kinshasa XI, D.R.Congo. \\ ${ }^{4}$ Département de Chimie, Faculté des Sciences, Université de Kisangani, Kisangani, D.R. Congo. \\ ${ }^{*}$ Corresponding author, E-mail: ptmpiana@yahoo.fr, Tel: +243818116019
}

\begin{abstract}
Anthocyanin crude extracts and fractions of Annona senegalensis leaves were screened for their antisickling properties using a validated in vitro bioassay model of sickle cell anaemia. Preparative thin layer chromatography of acetylated anthocyanin crude extracts carried out with chloroform as solvent provided two active fractions named $\mathrm{Ac}_{1}$ and $\mathrm{Ac}_{2}$. Fraction $\mathrm{Ac}_{2}$ was quantitatively isolated and submitted to physicochemical investigations. Thermo-degradation kinetics of the above fraction $\mathrm{Ac}_{2}$ at $80{ }^{\circ} \mathrm{C}$ and $100{ }^{\circ} \mathrm{C}$ revealed first order reaction with the rate constants $\mathrm{k}\left(\mathrm{s}^{-1}\right)$ of $8.1010^{-4}$ and $11.010^{-4}$, respectively. Anthocyanin crude extracts and the separated fractions showed in vitro antisickling activity. This activity justifies the use of this plant by congolese traditional healers; thus anthocyanins could be the major active principles. However, these natural pigments are unstable towards UV-vis light irradiations and heat. The conservation of this plant should then be performed in the absence of heat and/or light.

(C) 2012 International Formulae Group. All rights reserved.
\end{abstract}

Keywords: Sickle cell anemia, Annona senegalensis, anthocyanins, light irradiation, thermodegradation.

\section{INTRODUCTION}

The Democratic Republic of Congo (DRC) is reputed for the extraordinary richness of its flora and boasts a wide variety of medicinal plant species which represent an enormous reservoir of new molecules with potential therapeutic values (Debroux et al., 2007). All over Africa and particularly in DRC, the majority of people rely on traditional medicine for their health care needs; this is due to the fact that the conventional drugs costs are unaffordable
(Ngbolua et al., 2011). Drepanocytosis or Sickle Cell Anemia (SCA) is one of the illnesses for which the African population relies on medicinal plants for their treatment. SCA is a genetic disease which is endemic in some populations originating from subSaharan Africa, Asia and in some Latin and North African-Americans and AfricanEuropeans (Kaplan and Delpech, 1993; Fattorusso and Ritter, 1994; Voet and Voet, 1998; Iyamu et al., 2002; Moody et al., 2003). It is a hemoglobinopathy due to a substitution 
in position 6 within the $\beta$ chain of hemoglobin (Hb) whereby glutamic acid, a polar amino acid, is replaced by valine, a non polar amino acid.

This substitution decreases the affinity of $\mathrm{Hb}$ for oxygen. At low oxygen tension and when red blood cells (RBCs) are dehydrated, the mutant hemoglobin (Sickle hemoglobin or $\mathrm{S}$ hemoglobin) polymerizes inside the RBCs into a gel or further into fibers leading to a drastic decrease in the red cell deformability. Polymerization and precipitation of $S$ hemoglobin within RBCs cause the change of erythrocytes shape from their normal globular form into one resembling a sickle. Sickling of $\mathrm{RBCs}$ is the cause of precocious hemolysis of erythrocytes and various complications of sickle cell disease patients (Antonini and Brunori, 1971; Sofowora, 1975; Lehninger, 1994; Mpiana et al., 1996).

In Africa, SCA is a public health problem as $20-25 \%$ of the sub-Saharan population suffers from or transmits this disease. Two percent of the population of the DRC suffers from SCA. About $80 \%$ of children suffering from SCA do not receive medical care and die before the age of five years (Mpiana et al., 2007a).

Proposed therapies such as the allogenic medular transplantation remain very expensive for most African population. Some proposed antisickling drugs are toxic especially those requiring a long time of use (Mehanna, 2001). That is why African population recourse to medicinal plants in order to treat SCA (Newinger, 2000).

A review of literature on SCA chemotherapy revealed that a number of medicinal plants have been shown to contain antisickling principles in vitro (Bunn, 1997; Gentilini, 1986; Kuchel and Palston, 1993; Mpiana et al., 1996; Mpiana et al., 2010a, 2010b). Our previous findings also revealed that anthocyanins and triterpenoids are the major antisickling constituents of some Congolese and South African plants (Mpiana et al., 2007b, 2010c; Tshibangu et al., 2010).
As a continuation of our work on Congolese plants, Annona senegalensis Pers. was selected for investigation on the basis of its reported use against SCA in traditional medicine.

The main objective of this study was to verify if antisickling activity of the above mentioned plant is due to anthocyanin extracts as reported for others congolese plants (Mpiana et al., 2007a, 2007b, 2010c). In addition, since most traditional healers expose medicinal plants to sun and use decoction as the way of preparation of their recipes, we undertook to evaluate the effect of light and heat on the stability of these natural pigments.

\section{MATERIALS AND METHODS \\ Plant materials}

Plant materials (leaves) used in this study were collected in Kinshasa (DRC). Botanical identification was made by $\mathrm{Mr}$ Nlandu of the INERA (Institut National d'Etudes et Recherches Agronomiques) of the Faculty of Science, University of Kinshasa. Voucher specimens (A. Leonard 5635) are kept at the "INERA" herbarium service.

\section{Extraction, acetylation and phytochemical investigations}

The dried powdered plant material (10 g) was extracted by cold percolation with 95 $\% \mathrm{EtOH}$ and water $(100 \mathrm{ml} \mathrm{x} \mathrm{1)} \mathrm{for} 48 \mathrm{hrs}$. Extracts were filtered and the solvent was evaporated under reduced pressure using a rotary evaporator. A chemical screening was then done on the aqueous and ethanolic extracts of the leaves of Annona senegalensis. Several classes of compounds were screened, including alkaloids, polyphenols (tanins, flavonoids, anthocyanins and leucoanthocyanins), terpenoids and lipids. Extraction of anthocyanins was then done using $100 \mathrm{~g}$ of dried powdered plant material according to the universal procedures (Bruneton, 1999).

A quantity of $1.2 \mathrm{~g}$ of anthocyanin extracts was acetylated and $1.5 \mathrm{~g}$ of amorphous powder were obtained and 
subjected to thin layer chromatography (TLC) over silica gel $60, \mathrm{~F}_{254}$ aluminium barking plates from Merck, Germany. Chloroform was used as eluting solvent and plates were visualized under ultra-violet light at $254 \mathrm{~nm}$ and $366 \mathrm{~nm}$. Fractionation was carried out by preparative thin layer chromatography using silica gel.

The effects of radiations were evaluated by exposing anthocyanin solutions to a CAMAG UV lamp emitting a maximum wavelength of $366 \mathrm{~nm}$, while the thermal degradation was achieved using an oven (Telco model) at different temperatures and during different times. The absorbance of solution was measured using a Perkin Elmer Lambda 2 spectrophotometer.

\section{Blood samples and antisickling assay}

Blood samples were obtained from known sickle cell patients attending the "Centre de Médecine Mixte et d'Anémie SS" and "Centre Hospitalier Monkole", both located in Kinshasa area, DRC. None of the patients had been recently transfused. Blood samples were first characterized by haemoglobin electrophoresis in order to confirm their SS nature. All antisickling experiments were carried out with freshly collected blood. Blood samples were stored at $\pm 4{ }^{\circ} \mathrm{C}$ in a refrigerator. Ethical clearance on the use of SS blood was strictly observed according to international rules (WHO, 2002).

The antisickling activity of anthocyanins was evaluated using a validated in vitro bioassay model of SCA as reported elsewhere (Mpiana et al., 2007a, 2007b, 2010c). Briefly, A drop of $2 \%$ sodium metabisulfite in physiologic saline solution $(\mathrm{NaCl} 0.9 \%)$ is put on a glass slide. A drop of sickle blood (dilution $1 / 2$ with $\mathrm{NaCl} 0.9 \%$ ) is added and the slide is hermetically covered by a cover glass and the edges are clogged by melt paraffin wax. The slide is kept for $24 \mathrm{hrs}$ (incubation) in hypoxic conditions. After 24 hrs, RBCs became deoxygenated while adopting a sickled shape.
Normalization, defined as the passage of the sickled shape into the circular and normal biconcave form after treatments of RBCs with anthocyanin extracts, was quantitatively evaluated by measuring various cellular parameters such as area, perimeter and the radius using Motic Images package software. A zoom 6 x CANNON-type digital camera was used to convert the photonic micrograph image into a digital image, which was then digitalized using a MOTIC image 2000 1.3.

Mathematical model for thermal and photochemical degradations data analysis

Considering the thermal degradation of anthocyanins as a chemical reaction, an anthocyanin molecule A decomposes irreversibly into one or several molecules assigned as molecule B. This transformation can be schematically represented by the following equation as previously reported (Mpiana et al., 2009a, 2009b, 2009c, 2009d):

$$
\mathrm{A} \underset{\Delta}{\stackrel{\mathrm{k}}{\Delta} \rightarrow \mathrm{B}}
$$

The transformation is a first order decomposition for which rate equation is given by:

$$
-\frac{d C_{A}}{d t}=k C_{A}
$$

Where, $\mathrm{C}_{\mathrm{A}}$ is the concentration of $\mathrm{A}$; $\mathrm{k}$ the rate constant and the time of decomposition.

The integration of [2] gives:

$$
C_{A}=C_{A}^{o} \cdot e^{-k t}
$$

Where $C_{A}^{O}$ is the initial concentration of A. If $\mathrm{A}$ is the only compound that absorbs the light at a chosen wavelength, the BeerLambert relation for this case would be:

$$
E=\varepsilon l C_{A}
$$

And

$$
E_{o}=l \varepsilon C_{A}^{o}
$$


Where $\mathrm{E}, \mathrm{E}_{\mathrm{o}}, 1$ and $\varepsilon$ are respectively the absorbance at time $t$, the absorbance at time $\mathrm{t}=0$ second, the optic pathway and the molar extinction coefficient.

The combination of equation [3], [4] and [5] gives:

$$
E=E_{0} e^{-k t}
$$

If the compound resulting from degradation process absorbs simultaneously with $\mathrm{A}$ at the same wavelength, the BeerLambert equation would be:

$$
E=\ell\left(\varepsilon_{A} C_{A}+\varepsilon_{B} C_{B}\right)
$$

Where $\varepsilon A, \varepsilon B, C A$ and $\mathrm{CB}$ are respectively compound molar extinction coefficient and concentrations.

Considering that

$$
C_{A}^{o}=C_{A}+C_{B}
$$

And combining equations [3], [5], [7] and [8] provide

$$
E=E_{\infty}+\frac{\left(\varepsilon_{A}-\varepsilon_{B}\right) E o}{\varepsilon_{A}} \cdot e^{-k t}
$$

If $\varepsilon_{A} \succ \mathcal{E}_{B}$ equation [9] gives the same exponential decreasing trend as does the equation [6].

The experimental result fitting with the two models (equations [6] and [9]) is carried out using Microsoft Origin 6.3 software package.

\section{Statistical analysis}

The Student's t-test was used to test the significance of the difference between the results for treated and untreated SS blood samples. Statistical significance was set at $\mathrm{P}=0.05$. Data are expressed as means \pm S.D. Data analysis was performed using Microcal Origin 6.1 package software. The in vitro bioassay was performed in triplicate and the number of observed erythrocytes was determined using Thomas' cell as previously reported (Mpiana et al., 2010c).

\section{RESULTS}

The chemical screening carried out on the aqueous and organic extracts of the leaves of Annona senegalensis Pers revealed the presence of anthocyanins, tannins, flavonoids, leucoanthocyanins and alkaloids.

Thin layer chromatography (TLC) using ethyl acetate/petroleum ether (2:1) mixture as eluting system revealed three spots with frontal ratio values (Rf) of 0.54 , 0.68 and 0.94 respectively.

Thin layer chromatography using chloroform as eluent carried out on the acetylated total extracts of anthocyanins provided two spots $\left(\mathrm{Ac}_{1}\right.$ and $\left.\mathrm{Ac}_{2}\right)$ with $\mathrm{Rf}$ respectively 0.1 and 0.87 .

Figures 1 and 2 give the micrographies of the untreated and treated drepanocytes with the crude anthocyanin extracts. These morphological SS blood cells were observed in anaerobic conditions, i.e after deoxygenation of hemoglobin by $2 \%$ sodium metabisulfite solution. As it can be seen from the above images, the majority of non treated SS blood erythrocytes are sickled (Figure 1). In the presence of anthocyanin crude extracts of A. senegalensis, the shape of the erythrocytes are reversed and become normal, indicating the antisickling properties of anthocyanin extracts (Figure 2). Figures 3 and 4 illustrate modification of drepanocytes by acetylated anthocyanin extracts and $\mathrm{Ac}_{2}$ fraction respectively. Figure 3 indicates that despite acetylating, anthocyanins remain active. Figure 4, indicates that when treated with the $\mathrm{Ac}_{2}$ fraction, some erythrocytes preserve their sickle-shaped, suggesting that the antisickling effects of $A$. senegalensis anthocyanins may not be achieved by a single component. The calculated values of perimeter, surface and radius of untreated and treated sickle erythrocytes with the anthocyanin extracts are given in Table 1. 
Table 1: Average values of the perimeters, surfaces and the radius of untreated and treated sickle erythrocytes with anthocyanin extracts.

\begin{tabular}{lccc}
\hline Samples & $\begin{array}{c}\text { Cellular } \\
\text { perimeters }(\boldsymbol{\mu m})\end{array}$ & $\begin{array}{c}\text { Cellular surfaces } \\
\left(\boldsymbol{\mu \mathbf { m } ^ { 2 } )}\right.\end{array}$ & $\begin{array}{c}\text { Cellular } \\
\text { radius }(\boldsymbol{\mu m})\end{array}$ \\
\hline Control & $34.03 \pm 2.70$ & $21.41 \pm 2.01$ & - \\
Anthocyanin crude extracts & $19.51 \pm 2.54$ & $33.42 \pm 3.26$ & $3.30 \pm 0.51$ \\
Acetylated anthocyanins extracts & $20.01 \pm 2.13$ & $32.18 \pm 3.29$ & $3.10 \pm 0.53$ \\
Ac $_{2}$ (fraction) & $21.01 \pm 2.24$ & $32.23 \pm 3.25$ & $3.23 \pm 0.52$ \\
\hline Tabulated values are means \pm S.D. of statistical treatments of ten determinations according to Student's t-test (applied \\
with a probability threshold of 0.05 for 18 degrees of freedom (dof)), and enabled the determination of a significant \\
difference between the average values of both the cellular perimeter and surface of the untreated and treated sickle \\
erythrocytes. These results suggest that the effectiveness of the antisickling activity of A. Senegalensis could be related to \\
the anthocyanin extracts.
\end{tabular}

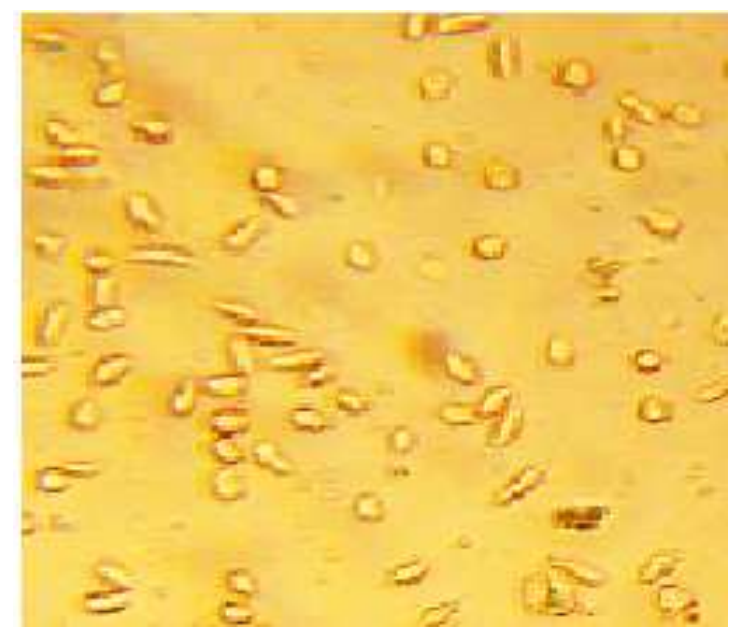

Figure 1: Morphology of untreated drepanocytes (negative control; X500).

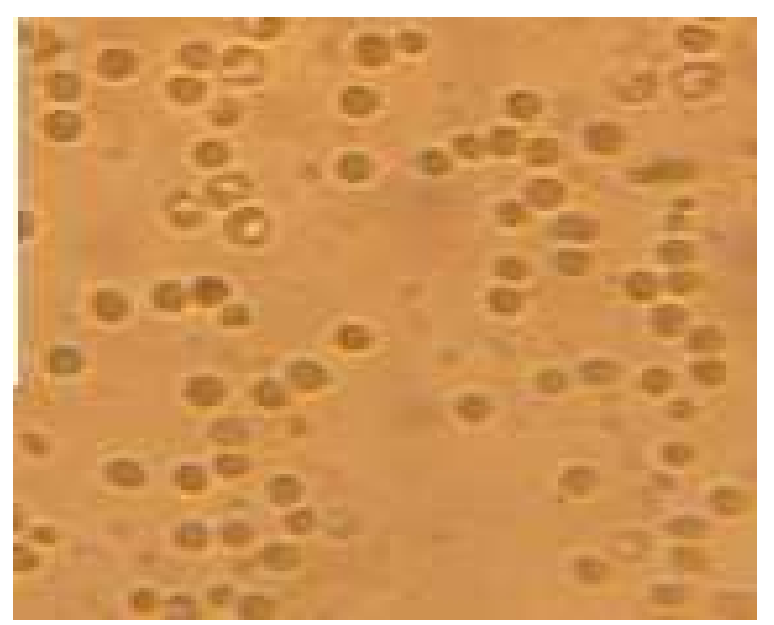

Figure 2: Morphology of drepanocytes treated with anthocyanin crude extracts (X500). 


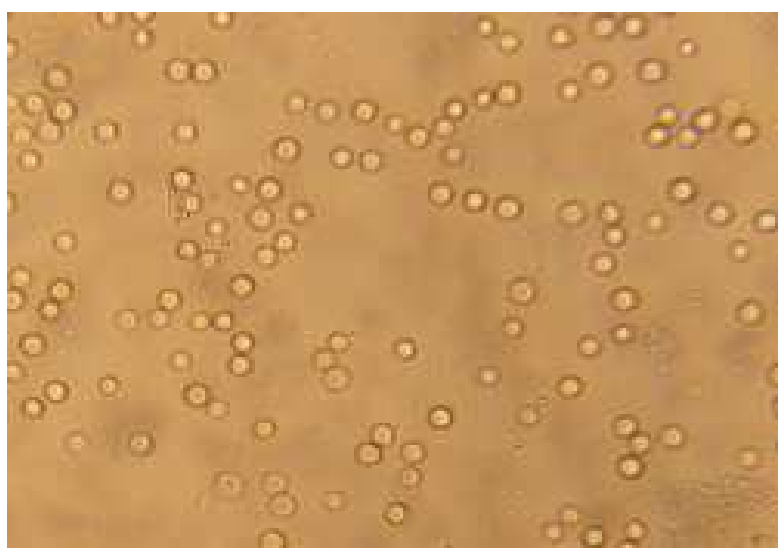

Figure 3: Morphology of drepanocytes treated with acetylated anthocyanin extracts (X500).

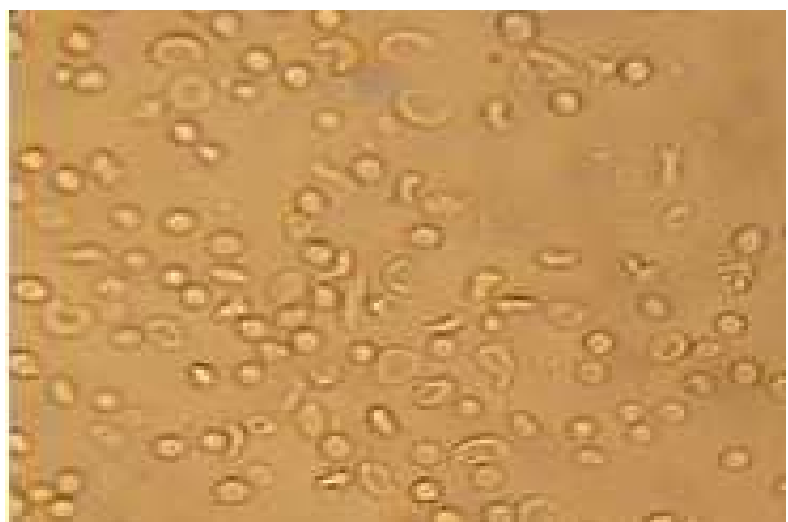

Figure 4: Morphology of drepanocytes treated with $\mathrm{Ac}_{2}$ fraction (X500).

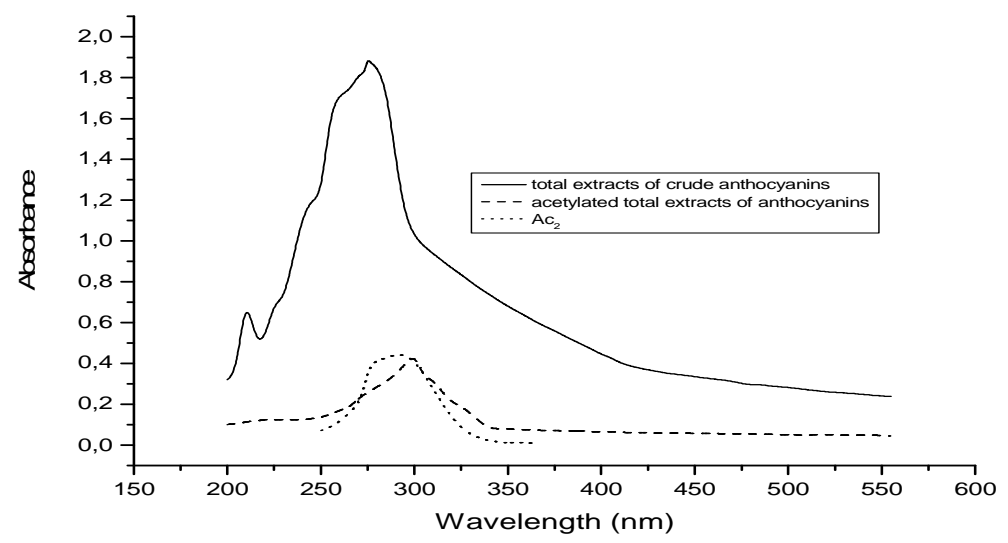

Figure 5: Spectra of the total extracts of crude anthocyanins, the acetylated total extract and the $\mathrm{Ac}_{2}$ fraction. 


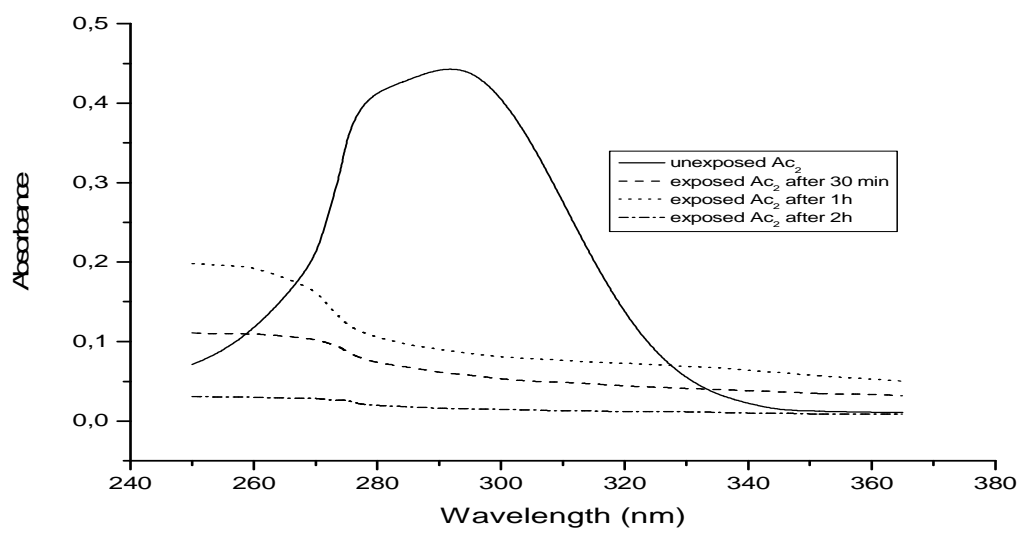

Figure 6: Spectra of $\mathrm{Ac}_{2}$ fraction before and after exposure to UV light at $366 \mathrm{~nm}$.

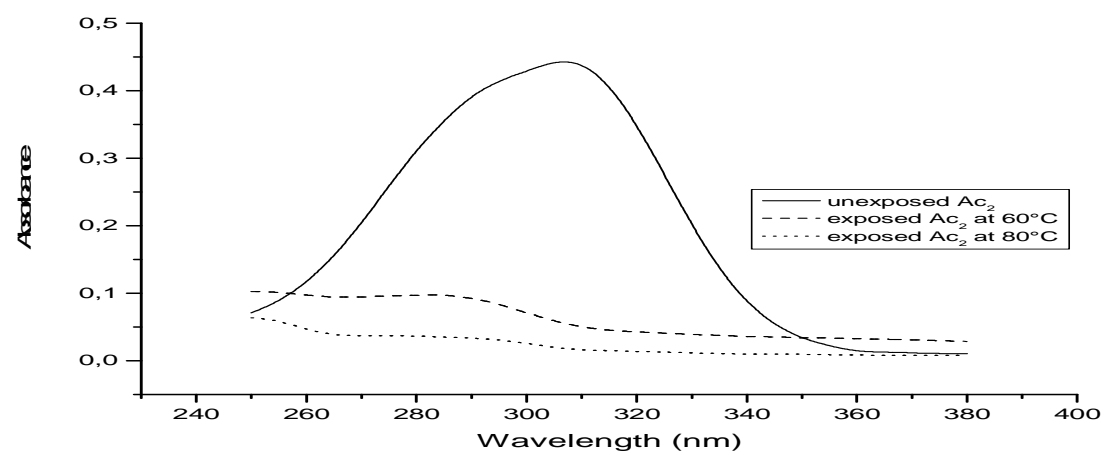

Figure 7: Spectra of $\mathrm{Ac}_{2}$ before and after heat exposure at $60{ }^{\circ} \mathrm{C}$ and $80{ }^{\circ} \mathrm{C}$ during 1 hour.

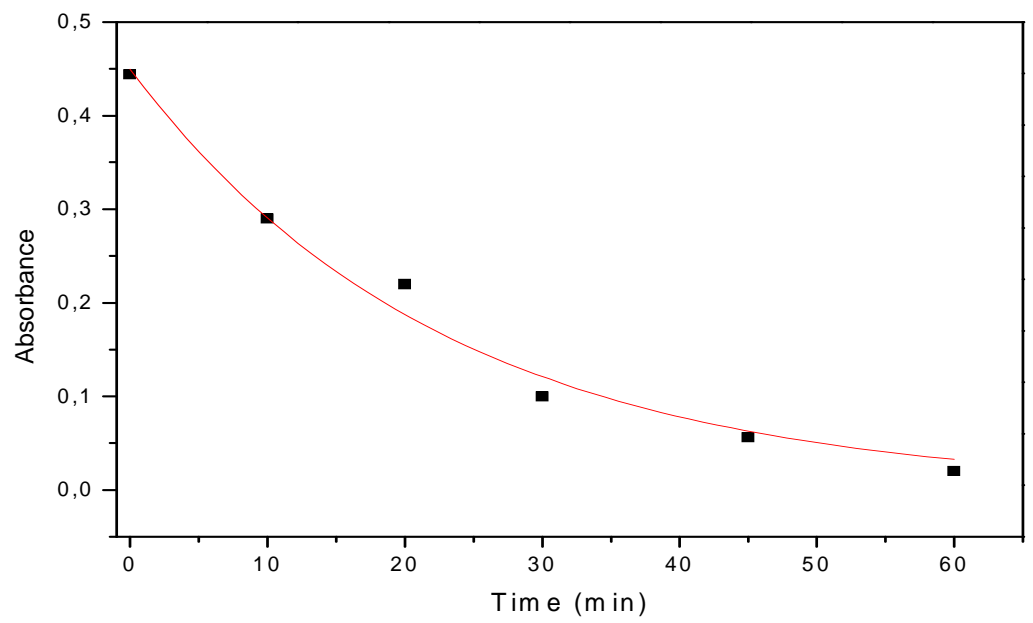

Figure 8: Absorbance evolution of $\mathrm{Ac}_{2}$ fraction according to the thermal treatment time at $80^{\circ} \mathrm{C}$. 


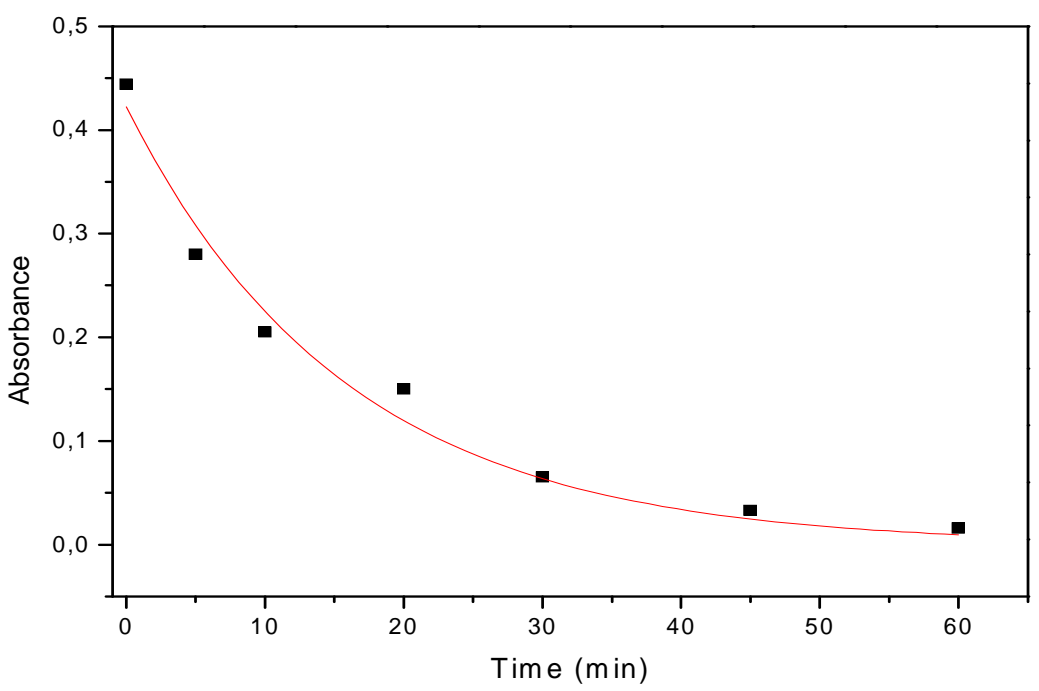

Figure 9: Absorbance evolution of $\mathrm{Ac}_{2}$ fraction according to the thermal treatment time at $100^{\circ} \mathrm{C}$.

The Figures 6 and 7 showed that the acetylated fraction of anthocyanins present an absorption band at about $310 \mathrm{~nm}$. This band drastically decreases after UV light exposure (Figure 6). The same result is also observed when the $\mathrm{Ac}_{2}$ fraction is exposed to the heat (Figure 7). Figures 8 and 9 show the thermokinetics curves of the $\mathrm{Ac}_{2}$ compound at 305 nm.

Thermo-degradation kinetics can be studied by monitoring the absorbance at different times for a fixed wavelength as shown in Figures 8 and 9. The decrease of absorbance of $\mathrm{Ac}_{2}$ fraction in these figures is fast at the beginning of the curve and slowing down with time. This decrease is more pronounced at $100{ }^{\circ} \mathrm{C}$ than at $80{ }^{\circ} \mathrm{C}$, indicating that the thermo-degradation is faster at a high temperature. These figures show the experimental points and the calculated curves according to the first order reaction model by assuming that both the reagent and the product absorb at $305 \mathrm{~nm}$ (equation [9]).

\section{DISCUSSION}

Compared to Figure 1, Figure 2 shows that in the presence of anthocyanin crude extracts of $A$. senegalensis, RBCs adopt circular/biconcave and normal shape, indicating the antisickling effect of anthocyanins. This normalization could be due to the inhibition of the $\mathrm{Hb} \mathrm{S}$ intraerythrocytic polymerization, and this is similar to other results reported in the literature (Iyamu et al., 2002; Nwaoguike and Uwakue, 2005; Mpiana et al., 2010c; Sahu et al., 2012). It should be noted that in the antisickling bioassays there is no established standard molecule that can be used as a positive control (Mpiana et al., 2010d).

On the other hand, anthocyanins are known for their instability (Bruneton, 1999; Mpiana et al., 2009a, 2009b, 2009c, 2009d). Thus, we hypothesized that their acetylation could increase their stability. That is why the anthocyanin extracts was acetylated and the antisickling activity of the resulting product was tested.

The perimeter, surface and radius were calculated for untreated and treated sickle RBCs with the anthocyanin extracts in order to confirm the modification showed by their micrographies.

Table 1 shows that the average radius for the RBCs of the sickle cell blood could not be calculated because sickled RBCs of untreated blood are not circular. The average radius appeared after treatment of sickle RBCs by anthocyanin extracts, indicating the 
re-appearance of the normal form of RBCs. This confirms previous results obtained with anthocyanin extracts from other Congolese plants (Mpiana et al., 2007b, 2009a, 2009b, 2009c, 2009d, 2010a, 2010b, 2010c).

The absorption band at $275 \mathrm{~nm}$ (Figure 5) are due to the $\pi-\pi^{*}$ transition of the flavylium ion which constitutes the basic structure of the anthocyanins. As already mentioned in the results section, the observed red shift may be due to the acetylation. Indeed, acetylation increases resonance in the molecule of anthocyanins and stabilizes the $\pi^{*}$ orbital, decreasing the difference in energy between the two orbitals, hence resulting in a displacement of the band towards the higher wavelengths (red shift). It should be noted that all these spectra present general characteristics of anthocyanins spectra in the UV domain (Kuchel and Palston, 1993; Mpiana et al., 2009a, 2009b, 2009c, 2009d).

These various spectra highlight the instability of the anthocyanins to UV light. The disappearance of the initially observed absorption band and the appearance of new bands around $290 \mathrm{~nm}$ after treatment indicate the sensitivity of the anthocyanins to the temperature. This justifies the need of preserving anthocyanin solutions at low temperatures and avoiding decoction or infusion recipes in traditional medicine. It can be noted that this behavior was observed for the anthocyanins extracted from other plants (Cissé et al., 2009; Mpiana et al., 2009a, 2009b, 2009c, 2010b).

The treatment of the experimental results by nonlinear regression according to equation [9] gave the values of the thermodegradation rate constants at $80{ }^{\circ} \mathrm{C}, \mathrm{k}_{80}=8.1$ $10^{-4} \mathrm{~s}^{-1}$ and $\quad 100{ }^{\circ} \mathrm{C}, \mathrm{k}_{100}=11.010^{-4} \mathrm{~s}^{-1}$. These values show that the kinetics of degradation is rather slow and are of the same magnitude order than those of the anthocyanins isolated from Ocimum basilicum and Hymenocardia acida (Mpiana et al., 2009d, 2010a).

\section{Conclusion}

In vitro antisickling activity observed in this study justifies the use of $A$. senegalensis by Congolese traditional healers and anthocyanins could be the major biologically active principles. This study shows that these natural pigments are instable towards UV-vis light irradiations and heat. Traditional recipes from this plant should be conserved in the absence of heat and/or light.

\section{ACKNOWLEDGEMENTS}

The authors are indebted to the International Foundation for Science (IFS) and the Organization for the Prohibition of Chemical Weapons (OPCW) for the Research Grant given to one of them for his $\mathrm{PhD}$ degree (Jean Paul Ngbolua KN, IFS Research Grant F/4921-2).

\section{REFERENCES}

Antonini E, Brunori M. 1971. Hemoglobin and Myoglobin in their Reactions With Ligands. North Publishing Co: Amsterdam.

Bruneton J. 1999. Pharmacognosie: Phytochimie-Plantes Médicinales. Tec \& Doc: Paris.

Bunn HF. 1997. Pathogenesis and treatment of sickle cell disease. N. Engl. J. Med., 337: 762-769.

Cisse M, Vaillant F, Acosta O, DhuiqueMayer C, Dornier M, 2009. Thermal degradation kinetics of anthocyanins from blood orange, Blackberry and Roselle using the Arrhenius, Eyring and Ball models, J. Agric. Food Chem., 57: 62856291.

Debroux L, Hart T, Kaimowitz D, Karsenty A, Topa G. 2007. Forests in PostConflict, Democratic Republic of Congo: Analysis of a Priority Agenda. Center for International Forestry Research: Jakarta.

Fattorusso V, Ritter O. 1994. Vade-mecum Clinique du Diagnostique au Traitement $\left(13^{\text {ème }}\right.$ edn), Masson: Paris.

Gentilini M. 1986. Médecine Tropicale. Flammarion: Paris. 
Iyamu EW, Turner EA, Asakura T. 2002. In vitro effects of NIPRISAN (Mix-0690), a naturally occurring, potent antisickling agent. British Journal of Haematology, 118: $337-343$.

Kaplan JC, Delpech M. 1993. Biologie Moléculaire et Médecine ( $2^{\text {nd }}$ édn), Flammarion Médecine-Science: Paris.

Kuchel PW, Palston G. 1993. Biochimie 1 : Cours et Problèmes. Mc Graw Hill Book Company: Paris.

Lehninger A. 1994. Principe de Biochimie. Flammarion: Paris.

Mehanna AS. 2001. Sickle cell anaemia and antisickling agents then and now. Cur. Med. Chem., 8: 79-88.

Moody JO, Ojo OO, Omotade OO, Adeyemo AA, Olumese PE, Ogundipe OO. 2003. Anti-sickling potential of a Nigerian herbal formula (Ajawaron $\mathrm{HF}$ ) and the Major plant component (Cissus populnea L. CPK). Phytother. Res., 17: 1173-1176.

Mpiana PT, Mavakala BK, Gushimana ZY. 1996. Effet du pH et ligand azide sur la dénaturation thermique de l'hémoglobine S. Bull. Soc. Chim. belg., 105(7): 369372.

Mpiana PT, Tshibangu DST, Shetonde OM, Ngbolwa KN. 2007. In vitro antidrepanocytary activity (antisickle cell anemia) of some Congolese plants. Phytomedicine, 14: 192-195.

Mpiana PT, Mudogo V, Tshibangu DST, Shetonde OM, Ngbolua KN. , Mbala MB. 2007. In vitro antisickling activity of Anthocyanins from Ocimum basilicum L. (Lamiaceae), Int. J. Pharmacol., 3(4): 371-374.

Mpiana PT, Mudogo V, Nyamangombe L, Kakule MK, Ngbolua KN, Atibu EK, Mbongo AK, Mbala MB. 2009. Ntumba JK. Antisickling activity and thermodegradation effect of anthocyanins extracts from Alchornea cordifolia (Schumach and Thonn) and Crotalaria retusa. Ann. Afr. Méd., 2(4): 239-244.

Mpiana PT, Balanganyi EK, Kanangila AB, Kalonda EM, Ngbolua KN, Tshibangu DST, Atibu EK, Lumbu JBS. 2009.
Activité antidrépanocytaire et thermodégradation des anthocyanes extraits de Sterculia quinqueloba et Ficus capensis. Int. J. Biol. Chem. Sci., 3(3): 551-560.

Mpiana PT, Mudogo V, Tshibangu DST, Ngbolua KN, Atibu EK, Kitwa EK, Kanangila AB Makelele LK. 2009. Activité antifalcémiante et thermodégradation d'une fraction d'anthocyanes extraits de Zizyphus mucronata. Ann. Afr. Méd., 2(2): 91-97.

Mpiana PT, Mudogo V, Kabangu YF, Tshibangu DST, Ngbolua KN, Atibu EK, Mangwala KP, Mbala MB, Makelele LK, Bokota MT. 2009. Antisickling activity and thermostability of anthocyanins extracts from a congolese plant, Hymenocardia acida Tul. Int. J. Pharmacol., 5(1): 65-70.

Mpiana PT, Mudogo V, Tshibangu DST, Ngbolua KN, Mangwala PK, Atibu EK, Kakule MK, Makelele LK, Bokota MT. 2010. Antisickling activity and thermodegradation of an anthocyanin fraction from Ocimum basilicum (Lamiaceae), Comprehensive Bioactive Natural Products, 3: 287-295.

Mpiana PT, Mudogo V, Ngbolua KN, Tshibangu DST, Atibu EK. 2010. In vitro antisickling activity of anthocyanins extracts from Morinda lucida Benth (Rubiaceae). In Medicinal Plants: Phytochemistry, Pharmacology and Therapeutics (vol.1), VK Gupta, GD Singh, Surjeet Singh Kaul A (eds). Daya Publishing House: New Dehli; 330-337.

Mpiana PT, Ngbolua KN, Bokota MT, Kasonga TK, Atibu E.K, Mudogo V. 2010. In vitro effetcts of anthocyanins extracts from Justicia secunda VAHL on the solubility of hemoglobin $S$ and membrane stability of sickle erythrocytes, Blood Transfusion, 8: 248254.

Mpiana PT, Makelele LK, Oleko RW, Bokota MT, Tshibangu DST, Ngbolua KN, Mbala MB, Atibu EK , Nshimba SM. 2010. Antisickling activity of 
medicinal plants used in the management of Sickle cell Disease in Tshopo district, D.R.Congo, Australian Journal of Medical Herbalism, 22(4): 132-137.

Neuwinger HD. 2000. African Traditional Medicine, Mepharm Scientifique Publisher, Suttgart.

Ngbolua KN, Hajatiana Rakotoarimanana, Herintsoa Rafatro, Urverg Suzanne Ratsimamanga, Mudogo V, Mpiana PT , Tshibangu DST. 2011. Comparative antimalarial and cytotoxic activities of two Vernonia species: $V$. amygdalina from the Democratic Republic of Congo and $V$. cinerea subsp vialis endemic to Madagascar. Int. J. Biol. Chem. Sci., 5(1): 345-353.

Nwaoguike RN, Uwawe AA. 2005. The antisickling effects of dried fish (tilapia) and dried prawn (Astacus red). J. Apllied sci. Envir. Management. 9(3): 115-119.

Sahu M, Singh V, Yadav S, Harris K. 2102. Plant extracts with antisickling propensities: a feasible succour towards sickle cell disease management- a mini review. J. Phytology, 4(3): 24-29.

Sofowora EA. 1975. Proceedings of Current Concepts in the Management of Sickle Cell Disease, Williams G (ed). NewOrleans sickle cell foundation: New Orleans, U.S.A.

Tshibangu DST, Shode FO, Koorbanally N, Mudogo V, Mpiana PT, Ngbolua KN. 2011. Anti-Sickling Triterpenoids from Callistemon Viminalis, Melaleuca Bracteata Var. Revolution Gold Syzygium Guineense and Syzygium Cordatum. In: African rain forests as source of drugs, The $14^{\text {th }}$ NAPRECA Symposium and AAMPS Ethnoveterinary Medicine Symposium, August 08-11, ICIPE, Nairobi, Kenya, pp. 296-300.

Voet D, Voet JG . 1998. Biochimie ( $2^{\text {nd }}$ édn). De Boeck Université: Paris.

World Health Organization. 2002. World Health Report: Reducing risks, Promoting Healthy Life. World Health Organization, Geneva. 